\title{
Faith-based Peacebuilding: Insights from the Three Main Monotheisms
}

\author{
By Paolo Salvatore Nicosia*
}

\begin{abstract}
Almost all world faiths consider peace as a central issue and religions can be a site of reconciliation or at least have the potential to become sites to prevent and solve local and global conflicts. Peacebuilding activities grounded on faith require not only social sciences standards to be studied, but also religious and spiritual resources such as ritual, prayer and spiritual healing, (along with other peacebuilding tools shared with secular experiences). The spiritual and religious resources can be analysed with standard measures of sociology, but the analysis would still not be complete and deep enough to understand their role in the empirical experiences of faith-based peace builders. One must consider also the moral and ethical issues that ground the theologies of all major world Religions, specifically in the Monotheisms that are the focus of this paper.
\end{abstract}

Keywords: Christianism, Faith, Judaism, Islam, Peace building.

\section{Introduction}

Considering the recent revival of religious based violence in all kinds of local and global disputes (Appleby 2000), there is an increasing need to apply religious principles and instruments to the practical work of conflict prevention and resolution. There is the need to develop the theory and praxis of faithbased peacebuilding, which is a relatively new development in the field of international relations, as a form of unofficial diplomacy: the so called "track two" diplomacy. It refers to "unofficial, informal interaction between members of adversary groups or nations that aim to develop strategies, to influence public opinion, organize human and material resources in ways that might help resolve their conflict" (Montville 1991: 162). The integration of the dynamics of religion faith with international peace building could combine reconciliation and conflict resolution in a creative way. In fact, faith based peacebuilding not only pursues the conflict resolution but mainly the restoration of a healthy and respectful relationship between the parties. It is interesting to notice that war is studied more in a variety of disciplines, from history to political science, from psychology to international relations, but peace seems to be more common, and religious related violence has much more references than religious related peace. Similarly, the percentage of time that war has on the media is much more in comparison to peace, probably because audiences are on average more interested in the first than in the latter. Also in everyday life, we consider more a small crime happening once than a long-lasting relationship among friends,

${ }^{*}$ Lecturer on Mediation and Peacebuilding, Free University of Bolzano, Italy. 
the day-to-day love of parents for their children, the social intercourse in the workplace with fellow workers and the common praying and worship as well as the several activities of solidarity among us.

While the need for conflict seems grounded in human history to fulfil or defend one's interest and needs in competitive ways, peace relates to ethics and the fulfilment of basic human needs based on cooperation. The need for cooperation in solving a conflict is related to the ethics of justice and to equity, which are possible because of the abstract rules that are innate in humanity. We normally learn in our experience as children, or when we look after them, that feelings of justice and fairness come quite early. They relate also to the denunciation of injustice and unfairness (in which the involved children can show conflict resolution attitude, in order to solve the dispute among themselves and even caring attitudes, more frequently than violent ones). From the humanistic and religious point of view, the ethic of care is involved and grounds almost every peace building, solidarity and relieving activity: in these cases, the moral agent seeks to do good around her or himself, taking care of the persons with whom she or he is in a relationship.

More than 20 years ago, the Council of the Parliament of the World Religions (1993), signed a Declaration on a Global Ethic based on the considerations of the theologian Hans Küng's comprehensive ethic of humanity. This ethic cannot derive from human rights alone, but it must also consider the human responsibilities, which were there before the law statements. The inclusion of the Golden Rule: "So whatever you wish that others would do to you, do also to them, for this is the Law and the Prophets" (The New Jerusalem Bible, Matthew 7:12) as the second principle of the Declaration on a Global Ethic is central from a care perspective. It implies a universality of humankind based on the reality that every human being can empathize with any other because all share the same nature and the same basic values. Essential human aspirations and needs are more or less the same for everyone: survival, security, nourishment, freedom, connectedness to family, group and culture. The Golden Rule principle is a responsibility of all in the spirit of a global ethic of care, and the solidarity that it pursues relates to tolerance, that is accepting each other in the unique or particular features that each represents. The value of personal tolerance leads to mutual toleration of other cultures, groups, peoples and nations, which means a concrete contribution to peace, the prevention or solution of conflicts or the possibility of managing them constructively. These moral principles are common in all religions of the world, as is peace. The hypotheses of this paper is that some basic peace tools, approaches and understandings in the Three Main Monotheisms should be more clarified, studied and expressed, to foster peace efforts grounded on the theologies and praxis of faith-committed persons and organizations. In particular, in the paragraph on Judaism, the focus is on its main peace-tools and the approaches of two fundamental authors of the last century. The paragraph on Christianity highlights the main tools and practical theologies involved in Christian-based peacebuilding. The paragraph on Islam 
gives evidences of the fundamental references and historical experiences of this religion to ground peace instead of violence.

\section{Peace Tools and Approaches in Judaism}

Starting from Judaism and the Old Testament, the word shalom is repeated more than 2,500 times in classical Jewish sources (Gopin 2000:77): it means wholeness, fulfilment, completion, unity and wellbeing. The meaning of shalom is profoundly positive, as it involves safety, felicity, the freedom from oppression and a well-being that comprises the individual, all humanity and the entire world. Shalom denotes everything that is implied in God's blessing and embraces much more than merely the absence of war; it has a social and relational meaning, that can be expressed in trust and table fellowship (Stendenbach 2006). This ethical principle has its origins in the Semitic world of the Old Testament: in particular, according to the Pentateuch, a faithful follower of God must attempt a relationship of hospitality, even with a stranger from a hostile tribe. The principle of hospitality is a sacred duty affirmed in the Old Testament. It is not only a positive principle, based in the Semitic culture: its importance is confirmed by the fact that no-hospitality is severely condemned. The citizens and the town of Sodom (The New Jerusalem Bible, Genesis 19) are destroyed because they wanted to commit collective violence against strangers, rather than hosting them; and moreover those strangers were angels, emissaries of God. Shalom comes about when human beings turn to God and live their life in communal relationships; it signifies the steadfast love of God and the endurance of the human's covenant and includes the forgiveness of sins and the withdrawal of their consequences, bringing harmony and peace into a world divided by violence. Certainly, different interpretations can serve the opposite purpose and, in the worst case, legitimize violent actions: it is clear that only the construction of a peaceful interpretation of Scripture can bring the necessary knowledge for identifying the ways in which violent interpretations can be countermanded and peaceful interpretations further developed.

An interesting and practical conflict resolution device from the Judaic sources is cited in Exodus, a central book of the Old Testament: "If you see the donkey of one who hates you lying down under its burden you shall refrain from abandoning him with it and shall rescue it with him" (The New Jerusalem Bible, Exodus 23: 5). Helping the enemy with a burden could change his opinion and behaviour: it is a classic example of a strategy involving unilateral gestures, which cause cognitive dissonance in the enemy, which in turn is designed to cause rethinking of the cognitive structure of the self and enemy (Gopin 2000: 78). This passage can ground Jewish conflict resolution theories, applied to individuals as well as to large groups, in order to fulfil the letter and spirit of this Exodus law. Other mediation and reconciliation patterns could include strategies of this psychological sort: authentic gestures of aid to an enemy or an enemy group, in order to change their attitudes in response to an 
unexpected and positive act performed by the other part. Exodus 23:5 is also an expression of something that is not only a conflict resolution strategy, but an activity that humanizes the enemies, making them object of help and support and not an incarnation of evil.

Another method of conflict resolution that has ancient Jewish roots is the so-called "shuttle diplomacy" (Gopin 2000: 136-137). This form of peacebuilding has deep Talmudic roots referring to Aaron, the high priest, brother of Moses, who in case of disputes did not sit people around a table conducting a dialogue of negotiation. Aaron went to one conflicting party, listened to all of his pain, told him constructive things, waited until the pain left his heart and then went to the other one and did exactly the same thing. Apart from the spiritual grounding of this procedure, the core elements of shuttle diplomacy are: honouring both sides by entering into their own spaces and respecting the boundaries of their world; active listening; emotional comforting; lengthy engagement with the parties, thus building trust over time; making all possible efforts to create a new relationship between the alienated parties. The end-result of this process, according to the rabbinic narrative, is that the parties often admit that each of them had misjudged the other. The result of the conflict resolution coming from such sort of awareness would not just be a problem solved, or a compromise found, but the kind of reconciliation that leads to physical embrace.

An important issue in Judaic peacebuilding is forgiveness (very important also for Christians, as we will see), that plays a fundamental role in religious responses to conflict, prevention and reconciliation of relationships that experience division and dispute. The Rabbinic Judaism emphasizes forgiveness as something that demonstrates a process of change, initiated by the person who did something wrong. From this point of view, there is a continuum in a story of conflict, change and forgiveness that should be embedded in the much larger practice and metaphysical reality of teshuva (Appleby 2003: $243 \mathrm{ff}$ ). Teshuva could be translated as repentance, returning, transformation or restoration of the capacity to transform oneself or a community and is considered to be one of the most sublime elements of faith in a good, forgiving God. From a legalistic point of view, we know that repentance can change a guilty verdict, but teshuva is much more than this: God is the ultimate knower of sin and knows how guilty everyone is in reality, not considering the sins that are occasionally witnessed in public. God continues to sustain human beings, to nurture their bodies from moment to moment, knowing full well the extent of their failings, and this is seen as almost a blessing, being like a perpetual commitment to mercy, forgiveness and patience. In interpersonal terms, forgiveness involves a bilateral, formal process in which a part admits his or her faults to the victim, who forgives the perpetrator.

Beyond forgiveness, other processes can be found in the Judaic peacebuilding processes, that develop something divine in human relations: a great sense of humility in the disputants, a discipline of patience for long periods of time, an avoidance of arrogance in relation to others (especially to enemies), control of anger, willingness to surrender positions (sometimes, even 
being right), the capacity to listen actively and, even more, to keep silent. Patience plays a key role in the forgiveness process and in creating adequate space for healing to occur: it involves a kind of self-sacrifice that is particularly difficult among the conflicting parties and certainly more for the injured parties to put into practice towards the perpetrators of a crime. The self-sacrifice involved in patience is grounded on a temporary suspension of the demand for immediate justice based on ordinary rules, but a willingness to focus on the transformation of relationships, in which the needs and demands of justice will be more fully realized. On a deeper faith level, patience based on religious grounds, especially as an emulation of God, indicates an expansion of one's perspective, in terms of the future transformation and evolution of the present relation, rather than from the past situation demanding something in the present.

Each person should emulate God as the one who facilitates to wipe away the people's sin, so each person involved in a conflict should wipe away the sins of his or her fellow human being. By virtue of this personal involvement in improving the life of the other, helping him or her with his or her failings, the offender should become too ashamed to revert to his-her old behaviour in front of the one who is generously wiping away their sins. This generosity should extend even to the point of absorbing insults, notwithstanding the classic conflict resolution theory and psychology that suggests that none of these insults, large or small, should be tolerated. We know that everyone tolerates insults, in order to preserve their most cherished relationships, for example the majority of parents towards their children. This is true for some Judaic peacemakers, especially religious ones, who show a deep sense of care for the parties: they believe in a common humanity, or the common origins in God, so they apply to others a level of tolerance that is normally reserved for family members or loved ones.

A true Jewish peacemaker (Gopin 2003) always acts as if he or she is the bridge between his community and the enemy community, being able to maintain mitsvot, divinely mandated deeds in Jewish tradition. He should seek to emulate all the divine characteristics mentioned earlier towards the enemy but should also express all of the love for the Jewish family that the biblical and rabbinic tradition requires. He must extend a helping hand to the suffering enemy, as Exodus 23:5 demands, at the same time as expressing the special love of his people that the Torah expects. Most prominent in the rabbinic notion of repentance is confession, which contains within it the elements of specifying the wrong done, regret and a commitment to a completely different future. It should be noted that the Day of Atonement, that is the holiest day of the Jewish year, is a day completely devoted to repentance in the form of repeated confessions, which can be a profoundly healing element of social change. It is also a day characterized by great physical deprivation in the form of fasting, with an important element of offering one's body and one's self to God. Confession, regret and commitment to the future is a powerful antidote to the damage done to victims: it addresses their need for their story to be 
acknowledged as true; it speaks to their memory, their basic sense of identity and of justice and their trust in a completely new future.

In relation to the theoretical approaches of Judaism to peace, a fundamental figure of the past has been Samuel David Luzzatto (Gopin 2000: 91-95, Luzzatto 1878). Luzzatto was one of the most pragmatically oriented thinkers in the history of Jewish thoughts; he was convinced that the compassion that Judaism commends is universal and extended to all God's creatures, with no exclusion of races, because all human beings are brothers, children of the same Father and created in the image of God. Even where there has been enmity or wrong done to the Jewish people by idolaters, such as the Edomite or the Egyptian, Luzzatto remembered that the Torah commanded tolerance. It is important to remember that the biblical texts that Luzzatto cited to prove his ideas involve the treatment of idolaters, not simply people that were not Jews; this conviction led him to consider that Jewish ethics would have to be considered universal. In fact, for example, the commandment to "love your neighbour as yourself" (The New Jerusalem Bible, Leviticus 19: 18) would have to be extended universally, meaning not only to Jews' neighbours. This perspective had revolutionary implications, since the Leviticus principle of neighbours' love has a complete meaning and prohibits envy, oppressive behaviour, profit of another's property and implies a prohibition of inaction when seeing the neighbour being assaulted or under mortal threat. The love principle of Leviticus is related also to positive and constructive commitments that have a social dimension, such as the balanced distribution of scarce resources and a moral guide that allows the poor to take what they need from the rich, but in an equitable way. Luzzatto's understanding of nature and what appeared to him to be irrefutable on a biological level, led him to conclude that only the social and human sentiments have the power to motivate human ethics and so create a good society. This means that, if God's wish is for human beings to be good, as it is shown by the biblical corpus, then the Torah must be founded upon the sentiment of compassion, especially for those who suffer and it should have no limits.

Another important figure similar to Luzzatto was Elijah Benamozegh (Gopin 2000: 99-106, Benamozegh 1994), who founded his vision of Jewish peacebuilding on a particular way of interpreting religion as universal. He was rabbi of Livorno and he stated that all the manifestations of God can be found in many religions and should be considered as vague reminders of the original conception of unity. In his conception Judaism is like a synthesis of the multiplicity and the diversity of the world's religions and their manifestations of the universal origin and unity. In this sense, Judaism can be considered as the glue that could ground a religion for the future, which returns the human race to a higher divine, human and cosmic unity. Because of this fundamental unity in the origins of religions and in their final goal, Benamozegh refused to condemn any other faith or form of worship: for him religion and faiths other than Judaism are not evil in the strict sense, but only incomplete. If all religions and faiths are part of the higher unity and are only incomplete in comparison to Judaism, at least faith in God can unite all peoples and all religions, avoiding or 
resolving conflicts. Benamozegh was also convinced that this unity could overcome the conflict between science and religion: he saw the challenge of religious diversity as no less important than the challenge of a world of chaos without scientific explanation. Religious diversity could be seen as a multiplicity of avenues to God, waiting for a higher synthesis to resolve the conflicts of religion, in the same way it could be for scientific laws: the united concept of God would solve both the religious crisis and the scientific quest for singular truth. Jewish life would be a particular means of a universal act to restore the original religion of humanity by teaching a higher synthesis, which removes the need for each religion to worship in opposition to others. In this perspective, Israel would not be the end but only a means in the accomplishment of the goal of a united humanity according, and the particularity of the Jewish people would be contingent to a limited time and would function as a driver to a universal religion. Peace would be indispensable for the process of reaching this universal religion, therefore the role of Jewish people would be as peacemakers among the nations, because of their commitment and their awareness of their specificities combined with a universal vision of the future. Moreover, since Jews have lived for centuries in non-Jewish cultures, often in dramatic tension, and they have developed a deep understanding of how to make a higher unity out of multiple particular identities. This is a vital principle of conflict resolution in situation of multiple ethnic and religious identities, aiming to create an international political community that embraces distinct nations but also a higher political unity of moral purpose. Benamozegh demonstrates how it is possible that even one of the most conservative religious traditions can become a part of this process, which has the best chance of generating peacebuilding patterns in every religion and faith.

\section{Peace Tools and Theologies in Christianity}

Talking about Christian approaches to peacebuilding (Friesen 1986, Sampson and Lederach 2000, Schreiter et al. 2010) it might be said that no theology is required for a faith founded on the incarnation of God, that calls for practical witnessing in life, following the example of Christ, the peacemaker par excellance between earth and heaven. It is clear that all theologies come out of specific Christian experiences and are in fact the reflection of Christian spirituality, practices and communities as mediating the reality of God. Peace building activities, in particular, can be seen as a global activity of the Christian churches and of Christian people, based in Christ's atonement and reconciliation in order to restore the goodness of creation destroyed by evil (or to restore harmonious relations out of conflicting ones). There is evil in its broadest sense as the antithesis of good and evil in the human world, which involves human intellect and will: sinful human relationships are evil relationships in which the basic humanity of other human beings is ignored or violated. Matthew's parable of judgment (The New Jerusalem Bible, Matthew 
25: 31-46) tells us that people who do not care about the needs of others are as culpable as those who directly cause another's sufferings. Evil is a complicated issue, which is also a matter of free will, about which human beings have choice and which makes it easier to assign blame and demand change. A theology of peacebuilding should be intended as a response to evil, since Christian peacebuilding assumes conditions of no peace, is performed in realities of violence, division and aggression, and tries to offer constructive alternatives of love, unity, compassion and forgiveness.

It is significant that, according to the Book of Genesis, Adam and Eve are the first human beings on earth: they sin together and break their relationship with God and with the entire creation (The New Jerusalem Bible, Genesis 3: 619). From that point onwards, humans enter a situation in which one rules over another, reflecting sin in all relations of unjust domination and the situation reaches an inevitable violent conclusion in the competition and fratricide of Cain and Abel. They clash over the value and rights of their work on the land and its social and religious significance; their relationship ends in the death of Abel and the exile of Cain (The New Jerusalem Bible, Genesis 4: 1-14) and will be redeemed for all by the death and resurrection of Christ. This scriptural references make us reflect that, besides recognizing the dynamic character of human existence, a contemporary view of nature and sin must correct the focus on the individual and social identity: individuals not only interact with their environment, but they are moral agents in the social relationships in which they are involved. It would be a mistake to see persons as if they were autonomous units not part of a global complex of social relationships that define their identities and the ways in which they are able to exercise choices. The Churches as a whole, representing the body of Christ, become an antidote to sin through the creation of resistant types of communities and relationships, in which belonging and identity are redefined as love of the neighbour, the enemy, the stranger and the poor. In relation to these aspects, some specific characteristic that are fundamental Christian peacebuilding patterns are: truth telling, pursuing justice, forgiveness and reconciliation (Schreiter et al. 2010).

Truth telling. The beginning is often the breaking of a culture of silence, which is a common experience in authoritarian societies where lies often replace other discourse about that society. The culture of silence is also quite common in socio-centric societies, where it can happen that abuses are often covered and people do not speak of unpleasant things. In individual western cultures, breaking the silence seems quite normal, but in socio-centric cultures, breaking the bonds of silence may mean breaking all the other social bonds that situate a person in society; also in the case of authoritarian societies, in which breaking the silence would mean putting the entire system in crisis. There are different forms of truth telling: objective or forensic, personal or narrative, dialogic (including the narratives of both victims and offenders); restorative or moral (that normally emerges at the end of a process of seeking and telling the truth). In the Gospel of John, Jesus declares himself as being the way, the life and the truth (The New Jerusalem Bible, Johannes 14:6) and the disciples are consecrated and called to abide in that truth, that makes the believers truly free 
(The New Jerusalem Bible, Johannes 8: 32). And in the Gospel of Mark, Jesus states clearly the fundamental and spiritual need and meaning of truth telling: "All you need say is 'Yes' if you mean yes, 'No' if you mean no; anything more than this comes from the evil one" (The New Jerusalem Bible, Mark 5: 37).

Pursuing justice (mainly in restorative ways). A fundamental part of the healing after a conflict is the need to pursue justice, which is important for the victims who have suffered in the conflict, but also for the broader aim of reconstruction the damaged or destroyed society. Reconstruction involves recently always public discussion and judgments of the wrongs that occurred during the conflict; this means often looking at how injustice may have been at the basis of the conflict, because by addressing the root causes of conflict, there are more hopes of overcoming them in the future. Punitive justice is, as the word itself indicates, a justice focused on punishment and it can have different purposes: punishing the wrongs that victims and society have suffered; deterring similar wrongdoings in the future and expressing no toleration towards such sins. From a religious perspective that grounds peacebuilding activities, punitive justice would in any case be inappropriate, if the enactment of justice itself would result in an unjust outcome. Restorative justice is definitely better from the Christian point of view. Restorative justice can be a distributive justice, which assures that the goods of society are equitable distributed, so in the specific case of a violent conflict, it implies the need to restore the dignity of the victims and to work to rehabilitate the offenders. The other type of restorative justice is structural justice and it focuses especially on the social structures of the society in which the conflict has grown, because every kind of inequity and discrimination contributes to conflict. In the Christian tradition, but also in the Judaic and the Muslim one, justice is one of the defining characteristics of God, who looks out especially for the poor and the oppressed. The consequence is that believers in God must pursue justice, which is when all human beings are in the right relationship with one another and with God.

Forgiveness. As for Judaism, also in Christian theology and peacebuilding forgiveness is a central issue, as a direct consequence of the Christian understanding of a merciful and loving God and from an understanding of the human being as a finite and limited being. The preaching of forgiveness was a major theme in Jesus' own ministry, either in the perspective of God that forgives human sins or from the perspective of humans that forgive one another. Related to this preaching, the Christian understanding of forgiveness focused mainly on the believer being forgiven of their human sins by God and on acts of individual forgiveness between conflicting parties, but less attention has been given to social forgiveness, which can be particularly important in the peace building processes. Forgiveness among disputants is generally understood as the giving up of the feelings of resentment that the victims have against the offenders, which results in the restoration of a social bond between them. From this point of view, forgiveness does not necessarily preclude punishment of the offender, also because punishment may be required by the law or the society. In any case, forgiveness may have different meanings, such 
as pardoning offenses, releasing parties from economic debts or receiving apologies. Taking responsibility for the inflicted pain is central to building a new relationship between victim and offender and there should be some ritual of apology, which gives the victims the opportunity to articulate the suffering experienced and tests the authenticity of the offender's remorse. Sometimes, if not often, a certain measure of forgetting the past is necessary to be able to focus on the future and reconstruct society, but forgiving does not mean forgetting: it means remembering the past in a different way.

Christian faith poses a higher challenge in forgiveness: according to the New Testament, God is so merciful and loving that He forgives the human beings not because of repentance but prior to it. This forgiveness should lead humans who have to repent and change life; in other words repentance should not be the condition but the fruit of being forgiven by God. In human discourses of peacebuilding among victims and oppressors, being inspired by such a great mercy, the victims could forgive their torturers and oppressor prior to and not as a consequence of their asking for forgiveness, with the hope that this forgiveness will lead them to repentance and change. In such a case, the forgiveness of the victims could have a gift-like and miraculous quality, making possible the ultimate goal of restoring justice that is to build a society in which all citizens can live as far as possible in freedom and harmony and in which, abusing the other would not occur again. We can say that forgiveness is central in Christianity and in conflict resolution; but the meaning and use of forgiveness is not a universal position even among Christians and in the different cultures that face conflict. So forgiveness can really play a crucial role in conflict resolution when it is consistent with individual cultures, because it interacts in various ways with moral and spiritual responses, such as commitment to truth, justice, apology, repentance and penance. This is even more important when these issues apply in cases of murder or genocide: in these cases the victims (or those who survived) and their oppressors need to do much more in order to transform the events that occurred in the past into a redemptive future.

Reconciliation. Reconciliation is at the same moment a process and a goal and cannot be restricted to reflecting the final state of peace. A theology of reconciliation should be able to accompany the reconciliation process at every step and for each possible outcome. Intermediate practical theologies could support the various steps in reconciliation: a theology of forbearance, seen as a gift of the Holy Spirit, can help people to accept one another and to live in peace with legitimate difference (The New Jerusalem Bible, Colossians 3: 1115). This is related to a theology of creating safe and hospitable spaces, a theology of reconstruction, a theology of a new narrative. Paul talks to Gentiles and Jews who had formerly been divided: now they are brought together through the blood of Christ into a common household of God and a complete process of reconciliation (The New Jerusalem Bible, 2 Corinthians 5: 17-20; Ephesians 2: 12-20).

There are three main points in reconciliation from the Christian point of view. Firstly, God is the principal author of reconciliation, but humans 
participate in this work of God as it is clear in the above mentioned second letter of Saint Paul to the Corinthians that explicitly call Christians into the work of reconciliation. This is especially important for every peace builder because it makes those working for reconciliation more centred on others and less on themselves, that is very important, because working in this field and for these goals often means being able to think out of the box. A theology of reconciliation focuses also on the spiritual discipline of prayer to which Christians are committed, because with the intimate conviction of being in communion with God is much more possible to help restore the communion that has been broken around. In this sense, the most important prayer is a contemplative one, waiting for God to speak rather than the opposite and learning to wait in silence, discerning God's voice and also the minimal movements in the processes of healing. Bearing in mind that reconciliation is ultimately God's work, the Christian peace-builders can consider themselves as His ambassadors and this can help to lift the heaviness of final responsibility in the peaceful outcome of a conflict. It helps also to lighten the psychological exhaustion that is common in peacebuilding, knowing that the spiritual discipline of prayer is no guarantee of avoiding the burnout, but it can alleviate some of the pressure. Everybody in such situations needs to find a place outside themselves and their own capacities from which to envision peace: this place for Christians is God. In every situation in which a prolonged conflict tends to harden opposing positions and things get stuck, there is the need to find new perspectives that can represent a way of getting unstuck. Secondly, in reconciliation, God begins with the victim and only then turns to the oppressor. This is built upon the message of Israel's prophets and the ministry of Jesus: go first to the orphan and the widow, the prisoner and the stranger. Saying that the healing begins with the victims means also giving them an immediate answer or at least attention, since it is a common awareness that justice usually takes a long time and the cause of victims is not suspended in the meantime but it is possible to find ways to begin the healing. For example, it is possible to restore the humanity of the victim, that is something which has been denied in the period of the conflict, or that has been a consequence of overt violence and other forms of oppression. A restoration of communion with God, where His presence is experienced as a healing force, can be a pillar in the process of restoring the humanity of the victim. On the other side, the oppressor has lost some or a lot of humanity in behaving as he/she did to the victims and can be helped through practices of conversion, remorse and acts of expiation, apart from the justice processes. Remaining on the relational and spiritual side, this expiation can be done through punishment or ritual separation from the community, if necessary, in order to restore the perpetrator's humanity and membership in the human family or in the specific community. Thirdly, in reconciliation, God makes a new creation also and especially from the history of the victim and the oppressor and this does not mean necessarily a restoration of a status quo ante but takes them to a new place, which has not been projected on their own nor by the peace builders. This can mean that the victim could not fulfil the dream about returning to where they were before the 
oppression happened, which is presumably the first goal for displaced persons, refugees and exiles. Even if they are eventually able to come back to their own place, it is concretely possible that they don't find what they left: they can find destroyed homes or somebody else living there, which are the most common reasons why it is difficult to resettle displaced persons and refugees. In cases in which the victims suffer the consequences of torture or mutilation or the loss of a loved one, there is no possibility even to come back to the past; the only way to overcome that past is by moving forward. Reconciliation in these situations focuses on the accompaniment of the victims on their path of healing, which can involve either physical healing or the healing of memories, to overcome the effects of one or another trauma.

The term reconciliation can have different meaning and interpretations. The Christian tradition of reconciliation has developed some distinctive ideas, mainly at the level of practical theology, that continue to inform concrete peace building processes and are linked to issues such as truth telling, justice, memory, healing and forgiveness. The Christian goal of reconciliation can be fulfilled in relation to a faith in a merciful and everlasting God: themes of healing and forgiveness are seen as part of that bigger picture, without which reaching reconciliation as a goal cannot be achieved or loses its deepest sense, which is its vertical dimension. Also at the level of human relations, the vertical dimension is essential for peacebuilding activities that focus primarily on larger scale phenomena such as societies and international relations. At the same time, they do not ignore the horizontal dimension of individuals and small groups, because peace agreements signed by leaders in society cannot guarantee their implementation, on the contrary, agreements at a higher level can exacerbate grassroots conflicts. Horizontal reconciliation, that is among human beings, either individually or socially, is rooted in the vertical reconciliation involving the leaders and, for Christians, in God's reconciling work. For believers, the human capacity alone cannot bring large scale reconciliations or cannot be so deep as to heal the damage that conflict and violence have produced, because of the different magnitude involved.

The last but not least point to consider, is the centrality of Jesus Christ in Christian faith. His being near to despairing sinners, as well as close to innocent victims, demonstrates his full humanity and, with the exception of sin, his unification of this humanity with the divine. In the incarnation God enters into every aspect of human suffering, including both oppression perpetrated and suffered. This reaches its highest point on the cross, that in the discourse related to peace building unifies the innocent victims of the violence of others, with their oppressors who caused their suffering and also those who don't care about it, trapped in their lack of empathy. A theology of peacebuilding can see the cross as the incarnation of God into the human condition of guilt as well as of innocent suffering in order to restore relationships and communities that have been broken. Theologies of the cross are practical theologies that respond to different wounds in the human situation and commend the Christians ways of healing those wounds. It must not be forgotten that theologies of the cross imply a resurrection experience, which means the transformation of death into 
everlasting life: being with humans in their suffering of every kind, God also transforms human existence and conflicts into something constructive forever. The practical implication for Christian practices of peace building is their impact on the larger society: this means working for social change, on the belief both in the enduring goodness of creation and of human nature, and in the promise of redemption based on the resurrection in Christ. He is the Word (of God the Father) made flesh, who maintains an intimate union with the Father and is present in believers united in the Spirit of God, forming the Church in its various expressions. This belief affects Christian spirituality, communities and practices, based on the nature of the incarnation and its emphasis in Christian conversion on prayer, contemplation, the transcendence of alienation and suffering and the cultivation of reconciling love in the community. Incarnation and resurrection inevitably have a strong connection to the healing of suffering and to social change, through the creation of inclusive communities based on love, compassion, sacrifice, forgiveness and mutual forbearance, providing a model of Christian identity and redemption that have a significant role in transformative peace building in the world.

\section{Peace Approaches and Understanding in Islam}

Looking at some insights of peace building from Islam, we have to consider that from the religious point of view, the word Islam means to enter into a state of peace, through the submission to God. We must also consider that the Qur'an is the fundamental source of Islamic law because Muslims believe it to be revealed by God along a period of time of about 21 years and it contains norms for all areas of life, including also conflict and the peaceful resolution of disputes (Abou El Fadl 2003: 179-185). But it would be not correct to equate the Qur'anic commandments with Islamic legal doctrine practice, because the meaning of the Qur'an is determined within a human context susceptible to numerous social and historical variations. In relation to conflict, the Qur'an commends Suhl (that means conciliation) as the superior moral course of action to be taken by disputing parties. The active form of the same commandments is Islah', that means to make something good, properly or to reconcile and settle. Reconciliation refers to different possible kind of amicable settlements, to compromises and to the willingness to submit the conflict to the decision of arbitrators (Hakam), for example in family disputes: "If ye fear a breach between them twain, appoint (two) arbiters, one from his family and the other from hers, if they seek to set things right, Allah will cause their reconciliation" (The Holy Qur'an 4: 35). Similarly for inheritance cases: "if anyone fears partiality or wrong-doing on the part of the testator and brings about a settlement among (the parties concerned) there is no wrong in him..." (The Holy Qur'an 2: 182).

In the Qur'an there are also general principles regarding peace and safety: "Wherewith Allah guideth all who seek His good pleasure to ways of peace and safety and leadeth them out of darkness, by His will, unto the light-guideth 
them to a path that is Straight" (The Holy Qur'an 5: 16). And again: "if two parties among The Believers fall into a fight, make ye peace between them: but if one of them transgresses beyond bonds against the other, then fight ye (all) against the one that transgresses until it complies with the command of Allah. But if it complies, then make peace between them with justice and be fair..." (The Holy Qur'an 49: 9). Clearly the peaceful and amicable settlement of disputes is considered a significant normative value in Islam, but are there exceptions to this rule? Are there situations where compromise and peaceful settlement of disputes are not desirable? This question is of particular relevance to the case of conflicts between Muslim and non-Muslims (particularly important in our days!). There is a Qur'anic verse that could confirm the principle of fighting non-Muslims: "Fight those who believe not in Allah nor the Last Day nor hold that forbidden which hath been forbidden by Allah and His messenger nor acknowledge the Religion of Truth, from among the People of the Book" (The Holy Qur'an 9: 29). There is another verse that commands Muslims to fight unbelievers, but in doing so, Muslims must not excess: "Fight in the cause of Allah those who fight you, but do not transgress limits; for Allah loveth not transgressors" (The Holy Qur'an 2: 190). The Qur'an continues: "...slay them wherever ye catch them, and turn them out from where they have turned you out" (The Holy Qur'an 2: 191) ...But it is immediately after in a certain sense corrected: "...if they cease, let there be no hostility except to those who practice oppression" (The Holy Qur'an 2: 193). A similar sequence of preparing to fighting remaining open to peace is contained in other verses: "Against them make ready your strength to the utmost of your power including steeds of war, to strike terror into (the hearts of) the enemies of Allah and your enemies... But if the enemy inclines towards peace, do thou (also) incline towards peace, and trust in Allah: for He is the One that heareth and knoweth (all things)" (The Holy Qur'an 8: 60-61).

There is also a Qur'anic verse, which leaves open the possibility of future friendship among Muslims and non-Muslims, that could overcome hostility: "It may be that Allah will Establish friendship between ye and those whom ye (now) hold as enemies, for Allah has power (Over all things); and Allah is OftForgiving, Most-Merciful. Allah forbids you not, with regard to those who fight you not for (your) faith nor drive you out of your homes, from dealing kindly and justly with them: For Allah loveth those who are just" (The Holy Qur'an 60: 7-9). Finally there is a verse about a specific situation that regards the relation of Muslim toward non-Muslims who wish to remain neutral not fighting with or against the Muslims: (Do not fight) "...those who join a group between whom and you there is a treaty (of peace), or those who approach you with hearts restraining them from fighting you or fighting their own people. If Allah had pleased, He could have given them power over you and they would have fought you..." (The Holy Qur'an 4: 90). We can then confirm that the peaceful resolution of conflict is a Qur'anic value among Muslims and, to a certain extent, also towards non-Muslims, but the real challenge is to determine its place in terms of a hierarchy of values (Abou El Fadl 2003: 186-187), where should peaceful conflict resolution be placed? If peace has a high priority, then 
at least some compromises would be justified if they lead to the peaceful resolution of the conflict; if not, pursuing this goal could be constrained by the need to respect higher purposes. It can be said that there is a proportional relationship between the willingness to compromise and the possibility of conflict resolution: this is always a difficult issue with hard-liners, that see the willingness to compromise as a lack of commitment to the truth, that by definition cannot be negotiated.

The challenges to the Islamic juristic tradition are posed today by modern nation states and they are not only related to the ability of Muslims to maintain peaceful relations with non-Muslim nations (Abou El Fadl 2003: 196-197). Also from the historical point of view, there are a lot of Islamic juristic precedents that support treaties of non aggression and cooperation with nonMuslims. The main challenge of the modern state is to the Islamic notions of the Shariáh, that represents the commitment of the state to a religiously based communal bond. Their implementation is considered to be that of the Divine Will, not necessarily the implementation of the collective will: in fact such an implementation presumes a Muslim citizenry. The Qur'an also focuses on them and this is inevitably reflected in a deeper and better implementation of the qualities needed to resolve conflicts (Nyang and Johnson 2003: 217-220), for example that the diversity of human beings must serve to encourage mutual understanding. This idea received attention among some Muslim jurists convinced that civil order is directly related to the development of effective interpersonal communications among human beings. This jurists have identified different kinds of negotiations one of which includes reconciliation with non-Muslims: examples are the treaties with non-Muslims in Egypt, Sham (Syria), Jerusalem, Armenia, Cyprus, Sudan and Nubia before the Western imperial era. Today Muslims and non-Muslims live together in many nation states where they are treated as equal citizens and this is consistent with the Qur'anic teachings relating to humanity as one community. Within Sunnism in particular, the practical expeditious and nonviolent resolution of conflict become a central, unifying value as a result of the successful resolution of disputes among Muslim factions. Negotiation settlements can and should become the religiously sanctioned means of limiting conflicts and preventing the escalation of destructive violence. The tradition calls Islamic authorities to act against those who refuse to accept a mediated, peaceful resolution to the conflict, forcing them to return to the negotiating table.

The last aspect to consider is that, after 9/11, Islam and Muslims have been more and more associated with terrorism by a large part of Western countries and population. An interesting insight after those events was given by AbuNimer (2003), that recognized a lack of knowledge among Muslims of the genuine peaceful values of Islam, that have been briefly described above. The author underlines that the notion of nonviolence has roots in religion in general and in Islam in particular and the western doctrine of "just war" (referring to the justification of violent means in order to bring peace), is not exactly the same as the concept of Jihad in Islam. He admits that the majority of Jihadist scholars are keen on focusing more on the conditions under which violent 
means are approved in Islam, that ultimately ends in a confirmation of the stereotyping of Islam as a violent religion. At the same time, scholars focusing primarily on the study of nonviolent principles in Islam have not been strongly supported in their challenge to the mainstream discourse, both inside and outside Muslim communities. He confirms the existence of the conflict resolution mechanism based on the Qur'an that have been highlighted before and practised in many Arab countries, such as Egypt, Jordan, Lebanon and Palestine. These mechanisms operate through the facilitation of third parties, according to the accepted traditional cultural norms guided by the Islamic principles to resolve conflicts. The disputants have a moral obligation to effect the final decision concluded by the third party after investigating the whole story of both. The final outcome, that should restore the damage and the relationship, is normally publicized to the whole community to enforce the respect of the agreement. Given this background in peacebuilding practices, the author suggests the potential for effective nonviolent conflict resolution trainings in Muslim communities, which could be vehicles for bringing about social change and countering the prevailing social diseases in many Muslim communities.

Finally, considering the overwhelming attention to extremist movements and the fundamentalist Islam they often espouse, an interesting exploration of peacebuilding and conflict resolution in contemporary Islam was edited by Qamar-ul Huda (2010). Similarly to the above mentioned Abu Nimer, the general concept is that Islam requires followers to preserve and protect life, to foster peace and tolerance. Again examples of peacebuilding efforts that can be found among Muslims and towards non-Muslims are highlighted, as well as advocates for Islamic principles of nonviolence and peacebuilding and traditional methods of conflict resolution. But it is clearly stated that all these positive and constructive aspects of Islam face serious challenges in the contemporary situation. Writing from their perspective as Muslim scholars and peacebuilding practitioners, the contributors underline that there are fertile grounds for effective peacebuilding efforts, fostering a culture of peace in Muslim communities and building effective conflict resolution practices to be developed in Islamic frameworks, engaging Muslim leaders, inside Muslim communities and in relation to the non-Muslims.

\section{Conclusions}

Religion's role in creating peace or violence must be seen as a part of a complete range of factors that generate violence or contribute to peacebuilding and conflict resolution in contemporary complex societies. From this point of view, there is a lot to do to build a constructive approach to the "Other", different to the members of one's own community, while maintaining a meaningful and authentic system of belief and practice in one's religion. After many centuries of extremely intolerant monotheistic religious warfare and in order not to remain passive in the face of the violence of today's extremism, it 
seems clear that the only way is to go forward, focusing on the positive elements that religion and society can offer. A lot of responsibilities remain in religious leaders, who should distance themselves from violence based religious approaches or, at least, present also the peace-related approaches of their religions, to counterbalance violence.

From a grassroots perspective, we have seen in recent times growing numbers of groups of believers who have embraced multi-faith contacts and exchanges. If one looks at a sampling of meetings and documents of recent decades, one discovers a remarkable level of commonality of both goals and values expressed by leaders and common people of many world religions. There are (and have been in the past) also in the three Main Monotheisms mandates for coexistence with Others that occasionally reign supreme: even if they are not the equivalent of the more unconditional guarantees of civil equality, they could form the basis for a better society in the future. This can and should be supported by religious people, especially those whose education runs wide and deep, to engage in a selective hermeneutic of their traditions that emphasizes what they share in common with the liberal humanitarian values expressed in the Universal Declaration of Human Rights. From this sociological point of view, we can draw a conclusion highlighting the most important question facing the interaction of religion and peacebuilding approaches in the multicultural, multi-religious and secular nature of most contemporary social settings. This means that faith-based peacebuilding could ground a creative interaction of people who are religious with secular, democratic constructs or with constructs from other religions and cultures; at the same time, the secular community can develop the courage and the humility to learn from the religious ones. This is a process that involves careful preparation, but can really encourage ways in which the communities can evoke from their own tradition the skills necessary to make peace.

\section{References}

Abou El Fadl K (2003) Conflict Resolution as a Normative Value in Islamic Law: Handling Disputes with Non-Muslims. In J Douglas (Ed) Faith-Based Diplomacy: Trumping Realpolitik, 178-209. New York, NY: Oxford University Press.

Abu-Nimer M (2003) Nonviolence and Peace Building in Islam: Theory and Practice. Gainesville, FL: University Press of Florida.

Appleby SR (2000) The Ambivalence of the Sacred: Religion, Violence and Reconciliation. Lanham, MD: Rowman \& Littlefield.

Appleby SR (2003) Retrieving the Missing Dimension of Statecraft: Religious Faith in the Service of Peacebuilding. In D Johnston (Ed) Faith-Based Diplomacy: Trumping Realpolitik, 231-258. New York, NY: Oxford University Press.

Benamozegh E (1994) Israel and Humanity (L Maxwell, Trans). New York: Paulist Press.

Friesen DK (1986) Christian Peacebuilding \& International Conflict. Scottdale. PA: Herald Press. 
Gopin M (2000) Between Eden and Armageddon. The Future of World Religions, Violence and Peacebuilding. New York: Oxford University Press.

Gopin M (2003) Judaism and Peacebuilding in the Context of Middles Eastern Conflict. In D Johnson (Ed) Faith-Based Diplomacy: Trumping Realpolitik, 106118. New York, NY: Oxford University Press.

Luzzatto SD (1878) Autobiografia di S.D. Luzzatto preceduta da alcune notizie storico-letterarie sulla famiglia Luzzatto [Autobiography of S.D. Luzzatto forwarded by some historical-literature news about the Luzzatto family]. Padova: Crescini.

Nyang S, Johnson D (2003) Conflict Resolution as a Normative Value in Islamic Law. In D Johnson (Ed) Faith-Based Diplomacy: Trumping Realpolitik, 210-230. New York: Oxford University Press.

Montville J (1991) Track Two Diplomacy: The Arrow and the Olive Branch: A case for Track Two Diplomacy. In VD Volkan, J Montville, DA Julius (Eds) The Psychodynamics of International Relations, vol. II: Unofficial Diplomacy at Work, 161-175. Massachusetts: Lexington Book.

Parliament of World Religions (1993 September 4) Declaration toward a Global Ethic. Chicago. Retrieved from http://bit.ly/29v8fzJ. [Accessed 9 June 2016].

Qamar-ul H (Ed) (2010) Crescent and Dove: Peace and Conflict Resolution in Islam. Washington DC: United States Institute of Peace.

Sampson C, Lederach JP (Eds) (2000) From the Ground Up: Mennonite Contributions to International Peacebuilding. Oxford, NY: Oxford University Press.

Schreiter RJ, Appleby SR, Powers GF (Eds) (2010) Peacebuilding. Catholic Theology, Ethics, and Praxis. Maryknoll, NY: Orbis Books.

Stendenbach FJ (2006) Shalom. In GJ Botterweck, H Ringgren, H J Fabry (Eds) Theological Dictionary of the Old Testament Vol XV, 28-39. Grand Rapids MI: William B. Eerdmans.

The Holy Qur'an (n.d.) Revised and edited by the Presidency of Islamic Researches. Retrieved from http://bit.ly/29viDaH. [Accessed 09 June 2016].

The New Jerusalem Bible (1985) Standard version edited by Henry Wansbrough. New York; London: Doubleday; Darton, Longman \& Todd. 